\title{
MANAGING ENVIRONMENTAL POLICY FOR TOURISM DEVELOPMENT
}

PhD Margarita Matlievska, Assistant Professor, Faculty of Economics, Goce Delcev University - Stip, Macedonia,
margarita.matlievska@ugd.edu.mk

PhD Biljana Petrevska, Assistant Professor, Faculty of Tourism and Business Logistics, Goce Delcev University - Stip, Macedonia, biljana.petrevska@ugd.edu.mk

\begin{abstract}
Based on variety of impacts that tourism poses over national economies, each country is interested in supporting its development. Moreover, everyone urges measures for increasing the number of tourists who are eager in meeting their travel and tourism preferences. Since the motive for tourism flows lies in natural or cultural background, it is necessary to find solutions for enhancing such basis. This paper supports the fact that tourism development may not be addressed if environment is neglected. For that purpose, the research is focused on environmental policy as a precondition for preserving safe and sound grounds for tourism development. In this respect, the case of Macedonia is investigated with its corpus of environmental laws being in a state of approximation with the 'horizontal' legislation of the European Union. So, the contribution of this paper lies in the fact that provides overview and facts at glance not only on the environmental protection legislation in Macedonia, but on the constitutional regulation as well. The research outcomes confirm the starting research hypothesis for obtaining national environmental legislation fully in line with already established international standards. Hence, one may argue that environmental policy provides basis and legal opportunities for strengthening tourism development.
\end{abstract}

Keywords: Environment; Tourism; Development; Management.

\section{Introduction}

It is more than obvious the existence of inevitable relationship between tourism and environment. Moreover, one may note that tourism is environment by itself. Without safe and well preserved nature, tourism will not be in a position to offer something sustainable.
So the aspect of developing management practices and philosophies that protect natural environments while reinforcing positive and orderly economic growth, must be addressed.

In this respect, Macedonia is one of the countries which have identified tourism as a mean for generating various micro and macro-economic impacts. Consequently, a National Strategy for Tourism Development 2011-2015 was prepared with a main vision Macedonia to become famous travel and tourism destination in Europe based on cultural and natural heritage. Yet, up-to-date the results in terms of economic prosperity by tourism development are modest, but the negative effects on environment cannot be stopped. Environmental pollution, depletion of natural resources, loss of biodiversity, ozone layer depletion, climate change, with all its severity imposed on the global scene. It becomes clear that to preserve the environment means preserving the life. Hence the tendency of each country declaring itself as a responsible one, to build legislation that would provide a higher level of environment protection as much as possible.

\section{Snapshot on environmental policy beginnings}

Since each country applies different approaches for legally regulating the environmental issue, they all urge to update and amend its existing legislation. As to the legislation concerning the protection and improvement of the environment, the 
European Union (EU) appears as a leader in the world.

Macedonia initiated the relations with the EU in 1992 with the main objective to become its member state. For this purpose, the government reaffirmed its readiness to join the Union by developing relationships and placing membership in the EU as a national goal of the highest priority. In 1995, Macedonia established diplomatic relations with the EU, and six years later in 2001, the Stabilisation and Association Agreement between the European Communities and their Member States, of the one part, and the former Yugoslav Republic of Macedonia, of the other part $^{5}$ (Council of the European Union, 2001) was signed. In 2004, the Government submitted the application for membership in the EU, and in 2005 it was given the status of a candidate country. The principle of partnership was legalized by a Decision in 2006, when the EU Council adopted the European Partnership with Macedonia.

The Membership requirement for a candidate country is to harmonize its legal system with the EU legislation, the so-called Acquis Communautaire that covers all membership obligations and criteria. The process of integrating the "European" law in national legal administrative system is called "process of approximation". It is consisted of three main components: legal transposition of EU legislation, its practical implementation and control of the implementation of legislation.

In December 2006, the Ministry of Environment and Physical Planning, as a governmental body responsible for environmental issues, adopted a new administrative and organizational structure in accordance with the different environment sectors. It corresponds to obligations imposed

\footnotetext{
5 Macedonia is the first country that signed Stabilization and Association Agreement with the EU in the region.
}

by transposed legislation in order of effective implementation of new powers and responsibilities. In order to meet the criteria for full membership, in April 2007 Macedonia adopted a National Programme for the Adoption of the Acquis (NPAA II). It contains plans for harmonization of national legislation with the EU and the necessary dynamics of institutional strengthening for the implementation of the legislation. Further on, the NPAA contains the necessary resources for the implementation and an Action Plan.

It is believed that the Environment Chapter is one of the hardest, most abundant and most complex chapters on implementation out of 33 EU Acquis Communautaire chapters. In the NPAA the environment is covered by Chapter 27 and is comprised of 10 sectors: horizontal legislation, water management, air quality, waste management, industrial pollution control and risk management, nature protection, forests, chemicals, genetically modified organisms and noise.

In the past period, Macedonia has adopted several policy strategic documents in several sectors of the environment. In most cases, the government policy aiming in improving the environment is clearly defined (Vision 2008, National Strategy for European Integration, National Environmental Action Plan II). Yet, the main responsibility for implementing the legislation is located in the Ministry of Environment and Physical Planning. One may note that other sectorial ministries have responsibilities in environment protection (Ministry of Agriculture, Forestry and Water Management, Ministry of Economy, Ministry of Transport and Communications, Ministry of Health, Ministry of Finance, Ministry of Interior).

The status of the transposition of EU environment legislation was perceived on the basis of the conducted legal analysis of the shortcomings of previous laws for different areas of environment. Generally, the legal 
transposition in different environment sectors is in a different stage, and in a significant number of directives, the transposition is in the early stages. However, it is very important the horizontal legislation transposition to get a high priority and to progress, because legislation in this sector has an impact on many other sectors. Furthermore, the Law on Environment belongs to horizontal legislation and therefore, it is important to assess the level of transposition with the directives of the Union.

\section{Constitutional approach towards environmental issue}

The Preamble ${ }^{6}$ of the Constitution of Macedonia reads: "The citizens of Macedonia, ...taking responsibility for the present and future of their fatherland ... and responsible to future generations to preserve and develop everything that is valuable ... ". From this formulation, it is obvious that the Constitution emphasized the accountability that present generation have in front of future ones to maintain and develop all that is worth keeping and developing, knowing that the descendants will collect the fruit. But what is it that is valuable, not only to preserve but to develop as well? The Constitution (Art. 56, par. 1) gives the answer to this question: "All the natural resources of the Republic of Macedonia, the flora and fauna, amenities in common use, ... are amenities of common interest for the Republic and enjoy particular protection. With this formulation, the Constitution transferred what Robert Redford thought when he said: "I think the environment should be put in the category of our national security. Defending our resources

\footnotetext{
${ }^{6}$ This is referred to in item 1 of Amendment IV of the Constitution of the Republic of Macedonia. Item 2 says: "Item 1 of this Amendment replaces the Preamble of the Constitution of the Republic of Macedonia." Amendment IV was published in the Official Gazette of RM No. 91 of 20 November 2001.
}

is just as important as defending abroad. Otherwise, what is there to defend?".

In this respect, the Art. 8 states that one of the fundamental values of the constitutional order of Macedonia is "ecological protection and development". So, the Constitution establishes fundamental human rights and freedoms, among which: Everyone has the right to a healthy environment to live in. Everyone is obliged to promote and protect the environment. The Republic provides conditions for the exercise of the right of citizens to a healthy environment (Art. 43). Furthermore, the Art. 43 , beside the right of every person to a healthy environment, determine his obligation to promote and protect the environment. In this line, the Constitution includes an obligation for Macedonia to provide conditions for enjoying the citizens' right to a healthy environment. The same article introduces a right and an obligation as well. In this context, it is important to note that the obligation is an integral part of the fundamental rights and freedoms of man and citizen. That is the reason that the constitutional text regulates the obligations along with fundamental freedoms and rights as an inseparable whole. The duty for environment and nature protection directly emanates of the human right to a healthy environment. And it must be so, if we want to come up with a change in our behavior towards the environment and if we want a certain change to prevail. It must be so if we want to respect what Gandhi said: "Be the change you want to see in the world."

With the Art. 55 (par. 1) "The freedom of the market and entrepreneurship is guaranteed." In the same article, par. 3 states that: "The freedom of the market and entrepreneurship san be restricted by law only for reasons of the defence of the Republic, protection of the natural and living environment or public health". From this article, it is evident that the possible negative impact on the market and entrepreneurship on 
nature and environment is anticipated, and, although the freedom of the market and entrepreneurship is defined fundamental value (Art. 8, par. 1, line 7) and the same is guaranteed (Art. 55, par. 1), it may be restricted by law for the reason, among others, of preserving the nature and environment. In this article, it is interesting that the nature and environment preservation is stated after the defense of the country (as the primary social interest of the citizens of each state), and even before the people health.

It is indisputable that the Constitution of Macedonia specifies the environment as a fundamental value, as a freedom and as a right. Furthermore it defines its protection and improvement as a duty and an obligation of the citizens of Macedonia. So, generally, it lays down the foundation and provides the basis for development of environment legislation. The first Law regulating the environment after Macedonia's independence was the Law on Environment and Nature Protection and Promotion (Official Gazette No. 69/96, 13/19, 41/00, 96/00 and 45/02) representing a framework law on environmental protection.

However, Macedonia's aspiration to become a member state of the EU imposed a need of preparing a new law, which was to meet the requirements in accordance with the obligations arising from the Union's so-called horizontal directives in this area. Consequently, the new Law on Environment was prepared and adopted in 2005 (Official Gazette No. 53/05, 81/05, 24/07).

\section{Overview on horizontal directives}

The rules apply to all environment media and waste, are part of the so-called Horizontal EU legislation and are regulated by the so-called Horizontal Directives. In the new Law on Environment, several horizontal directives of the EU are transposed.
The Directive 2003/4/EC ${ }^{7}$ addresses the issue of public access to environmental information. It aims to guarantee the right of access to information in the field of environment that are owned by the public authority or are possessed for the public authorities. This Directive makes an effort to ensure that the environment information progressively become more available. Further on, it secures that this information are published with the intention of their widest possible systematic dissemination to the public through electronic media and using computer telecommunications. It contains the terms in which public authorities should make information available and strictly defined the cases in which public authorities can refuse a request for information.

The Directive 2001/42/EC ${ }^{8}$ refers to the assessment of the effects of certain plans and programs on the environment. This directive is one of the more recent legal acts of the EU. Its goal is to enable a higher degree of environmental protection, as well as to contribute towards environmental issues integration when preparing plans and programs. This means that its intention is to guarantee the assessment of plans and programs that may have significant effects on the environment.

The Directive $85 / 337 /$ EEC $^{9}$ and the supplementary Directive $97 / 11 / \mathrm{EC}^{10}$ argue on the assessment of the effects of certain public

\footnotetext{
${ }^{7}$ Directive 2003/4/EC of the European Parliament and of the Council of 28 January 2003 on public access to environmental information and repealing Council Directive 90/313/EEC.

${ }^{8}$ Directive 2001/42/ec of the European Parliament and of the Council of 27 June 2001on the assessment of the effects of certain plans and programmes on the environment.

${ }^{9}$ Council Directive of 27 June 1985 on the assessment of the effects of certain public and private projects on the environment 85/337/EEC.

10 Council Directive 97/11/EC of 3 March 1997 amending Directive $85 / 337 / \mathrm{EEC}$ on the assessment of the effects of certain public and private projects on the environment.
}

Page | 68 
and private projects on the environment. This Directive regulates the environment impact assessment of public and private projects which are likely to have a significant environmental impact. The environmental impact assessment identifies, describes and assesses the impacts that a project has on humans, flora and fauna, soil, water, air, climate and landscape, material assets and cultural heritage.

The Directive 96/61/EC ${ }^{11}$ is concerned with the integrated pollution prevention and control. This Directive contributes towards achievement of integrated prevention and control of pollution arising from the activities or the activities of the installations listed in Annex I of the Directive. It is consist of measures designed to prevent or reduce emissions to air, water and soil as a result of the above mentioned activities, including measures concerning waste, in order to achieve a high level of environmental protection in general.

The Directive 96/82/EC ${ }^{12}$ puts an accent on the control of major-accident hazards involving dangerous substances. This Directive enables prevention of major accidents involving dangerous substances and limitation of their consequences for man and the environment in order to ensure a high level of environment protection in a consistent and efficient manner.

\section{Analyses, findings and discussion}

The level of transposition of European Horizontal Directives in the two Laws (the previous one - the Law on Environment and Nature Protection and Promotion, and the new adopted one - the Law on Environment) was the main criteria for undertaking comparative

11 Council Directive 96/61/EC concerning integrated pollution prevention and control, IPPC.

\footnotetext{
12 Ciuncil Directive 96/82/EC of 9 December 1996 on the control of major-accident hazards involving dangerous substances.
}

analyses. In doing so, we detected four areas as hot-spots that are differently regulated.

In this sense, the Law on Environment and Nature Protection and Promotion does not regulate precisely the rights and obligations regarding access to environment information and the right of access to justice, as well as the procedures for impact assessment of certain projects, plans and programs on environment. Furthermore, this law lacked provisions that would have provided the basis for ensuring integrated environmental management. This might have been the case through a separate system of integrated permits, as well as prevention and protection against accident hazards.

As to the first element, the rights and obligations regarding access to environment information and the right of access to justice, the national legislation contained several provisions relating to the active and passive dissemination of information, in various acts, but they were not clear enough. For example, the past law stated that data on quality and environmental phenomena endangering public, without explanation whether they should be actively disseminated or passively, simple with responding the request for information. In this law, interpretation of the provisions in this area was too limited to that which is in accordance with the definition of environmental information according to the Directive 2003/4/ES (as according to the Aarhus Convention ${ }^{13}$ (UNECE). According to that Directive, it was necessary to determine which bodies are obliged to disseminate information actively and to respond to the requests for information. The same Directive also contains provisions on the application of procedure and provision of information that should be considered when regulating this matter, as well as provisions for legal protection when the request for information is denied or insufficiently answered. So, the general impression is that

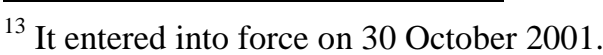


the legal framework in this area was weak (despite the efforts of the authorities for transparent operation), which required an entirely new approach - an approach that is contained in the new, Law on Environment.

Regarding the second element, the procedure for assessment of the impact of certain projects, plans and programs on the environment, in accordance with previous legislation, the adoption of plans and programs of the state administration was conducted with no assessment of their environmental impact. With the new Law on Environment, the procedure (laid down in Directive 2001/42/ES) aimed at the environmental consequences to be identified and assessed during the preparation and before the adoption of certain plans and programs was enforced. Pursuant to the Law on Environment, the public and the authorities can give their opinion and all conclusions are integrated and taken into account in the ongoing proceedings.

After the adoption of the plan or program, the public is informed of the decision and the way it was made. Moreover, the Government informs the public about its work and the annual program for implementation, while according to the Law on Local Self-Government, the municipal authorities have an obligation to inform citizens about the plans and programs that are important for the development of the municipality and public participation is only at the initiative of the citizens.

According to Directive 2001/42/EC, public participation is seen as an individual right and obligation of the competent authority and therefore it must be placed in a legal text, which is done by the Law on Environment ${ }^{14}$.

Further on, it should be stressed that the procedure for environmental impact

\footnotetext{
${ }^{14}$ Bylaws allow achieving full transposition of the Directive.
}

assessment of certain public and private projects (provided for in the Directives $85 / 337 /$ EEC and 97/11/EC) is associated with the procedure for building permit issuance. In previous legal practice in Macedonia it was not requested the opinion (which gives the body of the state administration responsible for the affairs of the environment) to be binding on the competent authority issuing a license to carry out the project, which was not in accordance with Directive. The public should be informed about the project implementation and it should be given the opportunity to express its opinions or to participate in the process of decision making. The inclusion of the public and the crossborder effects should be taken into account. Chapter eleven of the new Law, along with the bylaws (secondary legislation) provided in it, fully transposing this Directive.

Associated with the third element, integrated environmental management through a separate system of integrated permits, as an obligation to join the EU, the new Law provides a procedure and time limits for complying the economic sector with new norms and standards for the environment protection.

The EU has a set of rules for permits for industrial installations. All installations covered by Annex 1 of Directive 96/61 are required to obtain permission from the competent authorities in the country. If they do not have a permit, their operating will be banned. Permits must be based on the BAT concept (Best Available Techniques). For these installations, the Directive gives 11-year transition period to comply with the requirements of the Directive from the date of entry into force of this Directive.

Previous Macedonian legislation encompassed more types of permits related to the environment, but none of them was issued only by the state administration responsible for the affairs of the environment. With other words, environmental aspects were taken into 
account through consultation between ministries. By contrast, the Law on Environment developed a separate system of issuing licenses and it sets rules and deadlines for achieving conditions in a manner as required by the Directive permits and according to the experience of the Member States of the EU.

With regards to the fourth element, prevention and protection of accidents hazards, in the previous legislation, the measures to protect the environment and people from accidents caused by hazardous substances were contained in many acts. The new Law on Environment unifies activities and measures taken to damage prevention and protection in a single act and fully in accordance with the requirements of Directive 96/82/EC.

\section{Concluding remarks}

Since the Constitution of Macedonia guarantees the citizen the right to a healthy environment, simultaneously provides basis for tourism development. Based on fact that the Constitution also sets out the duty of the state to enable the fulfillment of this right, it means that it is spotted a necessity for planning and managing tourism flows. Without well preserved nature, Macedonia may not be able to fulfill strategic objectives.

The research found that the Law on Environment is a framework law made according to the pattern of western laws where basic principles and horizontal issues are regulated in one, basic law. The comparative analysis resulted with findings that this law is a kind of a general environmental law that covers common issues regulated by sectorial laws for the different environmental media and waste management, such as laws on water, on waste management, on nature protection and on ambient air quality. Furthermore, this law struggles to meet the requirements contained in the EU Directives that are approximated in it. Yet, the in-depth analysis showed that this law differently regulates matters regarding the environment. It determines and specifies the rights and obligations regarding access to environment information, and the right of access to justice. Also, this law sets out environment impact assessment procedures of certain projects, plans and programs. Additionally, it contains provisions that provide the basis for integrated environmental management, through a particular system of integrated permits, and provisions for prevention and protection against accidents.

So, the research findings stipulate that the Law on Environment establishes overall legal framework for management, supervision and protection of the environment in accordance with the principles of professionalism and competence, and provides a multi-sectorial approach to environmental protection. As so, it may serve as a solid base for enhancing tourism development issue. Generally, the current environmental policy confirms that Macedonia has an integrated environmental protection system, and regulation in line with established international standards in this area. Thus, one may argue the possibilities for providing background for integrated environmental management of tourism development.

\section{References}

1. Amendment IV of the Constitution of the Republic of Macedonia. Official Gazette of the Republic of Macedonia No. 91 of 20 November 2001.

2. Directive 2001/42/EC of the European Parliament ond of the Council of 27 June 2001on the assessment of the effects of certain plans and programmes on the environment. Official Journal of the European Communities. NO L 197/30. 21.7.2001. (Available at http://eurlex.europa.eu/LexUriServ/LexUriServ.do?uri =OJ:L:2001:197:0030:0037: EN:PDF).

3. Law on Environment and Nature Protection and Promotion. Official Gazette of the Republic of Macedonia No. 69/96, 13/19, 41/00, 96/00 and 45/02.

4. Law on Environment. Official Gazette of the Republic of Macedonia No. 53/05, 81/05, 24/07, 159/08, 83/09, 48/10, 124/10, 51/11. 
5. National Strategy for Tourism Development 2011-2015. Government of the Republic of Macedonia (2012). Skopje.

6. Stabilisation and Association Agreement between the European Communities and their Member States, of the one part, and the former Yugoslav Republic of Macedonia, of the other part. Council of the European Union, 2000. (Available at http://ec.europa.eu lenlargement/pdf/the former yugoslav repub lic_of macedonia/saa03 01_en.pdf).

7. UNECE Convention on Access to Information, Public Participation in Decisionmaking and Access to Justice in Environmental Matters. (Available at http://www.unece.org/env/ pp/treatytext.html).

8. Council Directive of 27 June 1985 on the assessment of the effects of certain public and private projects on the environment 85/337/EEC. Official Journal NO. L 175. 05/07/1985 P. 0040 - 0048 (Available at http://ec.europa.eu/environment/eia/full-legaltext/85337.htm).

9. Council Directive 96/61/EC of 24 September 1996 concerning integrated pollution prevention and control.
OFFICIAL JOURNAL L 257. 10/10/1996 P. 0026 - 0040. (Available at http://eurlex.europa.eu/LexUriServ/LexUriServ.do?uri =CELEX:31996L0061:EN: HTML).

10. Council Directive 96/82/EC of 9 December 1996 on the control of major-accident hazards involving dangerous substances. OFFICIAL JOURNAL L 010. 14/01/1997 P. 0013 - 0033. (Available at http://eur lex.europa.eu/LexUriServ/LexUriServ.do?uri =CELEX: 31996L0082:EN:HTML).

11. Council Directive 97/11/EC of 3 March 1997 amending Directive $85 / 337 / \mathrm{EEC}$ on the assessment of the effects of certain public and private projects on the environment. Official Journal No. L 073. 14/03/1997 P. 0005. (Available at http://ec.europa.eu/ environment/eia/full-legal-text/9711.htm).

12. Directive of the European Parliament and of the Council of 28 January 2003 on public access to environmental information. Official Journal of the European Union NO L 41/26. 14.2.2003.

(Available at https://www.elaw.org/system/files/EU.20034E CDirective.pdf). 